\title{
Mineral Separation and Characterization of the Ilmenite Ore Phases: Optimization of the $\mathrm{TiO}_{2}$ Pigment Process
}

\author{
M. Contreras ${ }^{\text {a,* }}$, M.J. Gázquez ${ }^{\text {a,b }}$, J.P. Bolívar ${ }^{\text {a }}$ \\ ${ }^{a}$ Department of Applied Physics, Faculty of Experimental Sciences, University of Huelva, Huelva, Spain \\ ${ }^{b}$ Department of Applied Physics, Escuela Superior de Ingeniería, Puerto Real, Cádiz, Spain
}

\begin{abstract}
The $\mathrm{TiO}_{2}$ production by the sulphate route uses ilmenite as raw material, which is initially milled and dissolved by adding concentrated sulphuric acid (98\%). A significant fraction of the original raw material (about 10-15\%) cannot be dissolved in the digestion step. In order to recovery the titanium (rutile form) and other economic minerals during the digestion stay, was carried out a deep characterization of the used raw material in relation to several parameters, such as the elemental composition (major and trace elements), mineralogy, microscopic morphology and physical composition. Therefore, the main goal of this work has been to separate and to analyse the minerals contained in the raw material in order to isolate the potentially dangerous and economics minerals prior to the industrial process. The main conclusion the study was that the raw material is mainly composed of ilmenite and its alteration products (ilmenite unchanged, leached ilmenite, pseudorutile, leached pseudorutile and rutile), produced by weathering of the original ilmenite, and containing small amounts of other minerals (monazite, spinel, quartz and zircon). According to this, a near total isolation of each mineral is very complex, but a high percent of them can be recovery by optimizing the industrial process. In addition, the economical impurities isolated can be commercial. Likewise, this fact could be reduced the potential environmental impact of the $\mathrm{TiO}_{2}$ industries via sulphate by reducing the waste production.
\end{abstract}

Keywords: Ilmenite; $\mathrm{TiO}_{2}$ industries; Magnetic mineral separation; Particle morphology; Textural constraints

\section{Introduction}

In opposition of the popular belief, the most widely used titanium product is not the titanium metal and alloys, but rather is the titanium dioxide $\left(\mathrm{TiO}_{2}\right)$ pigment. This pigment provides whiteness and opacity to a vast range of everyday products from coatings and plastics, to inks and even as flux in glass manufacture, filler in paper, rubber industries [1], cosmetics and food. Annually more than 4.5 million tons of $\mathrm{TiO}_{2}$ are produced worldwide [2] and only about $4-5 \%$ is used to produce metallic titanium [3].

Titanium is basically found in nature as ilmenite ore $\left(\mathrm{FeTiO}_{3}\right)$ either as a rock or as sand, rutile, anatase and brookite, which although they all have the same formula $\left(\mathrm{TiO}_{2}\right)$, but differing in their crystalline structure. In addition, leucoxene $\left(\mathrm{Fe}_{2} \mathrm{O}_{3} \cdot \mathrm{nTiO}_{2}\right)$ [4], is an oxidation product of ilmenite which it is composed of finely crystalline rutile. Other less common titanium oxidebearing minerals are pseudobrookite $\left(\mathrm{Fe}_{2} \mathrm{TiO}_{5}\right)$, perovskite $\left(\mathrm{CaTiO}_{3}\right)$, geikielite $\left((\mathrm{Mg}, \mathrm{Fe}) \mathrm{TiO}_{3}\right)$, pyrophanite $\left(\mathrm{MnTiO}_{3}\right)[5]$ and the only silicate mineral with titanium as a major component is titanite (known as sphene $\left(\underline{\mathrm{TiSiO}}_{5}\right)$.

Ilmenite is the most important economic mineral from which $\mathrm{TiO}_{2}$ is extracted; due to the content of $\mathrm{TiO}_{2}$ is about $50 \%$ and it is widely found. Despite that rutile, which is the richest form of $\mathrm{TiO}_{2}\left(93 \%-96 \% \mathrm{TiO}_{2}\right)$ occurring naturally but is not so often found in deposits valid for commercial use. Finally can be found as leucoxene $\left(\mathrm{Fe}_{2} \mathrm{O}_{3} \cdot \mathrm{nTiO}_{2}\right)$, a natural alteration product of ilmenite, containing often more than $65 \% \mathrm{TiO}_{2}[5,6]$.

More than half of the world's titanium production is obtained from ilmenite and rutile in shoreline placer deposits in Australia, South Africa, USA, India and Sri Lanka. Magmatic ilmenite deposits in Canada, Norway, Finland and USA supply most of the remainder. The magmatic deposits yield ilmenite with a $\mathrm{TiO}_{2}$ content of $35 \%-40 \%$, whereas the shoreline placer deposits

${ }^{*}$ Corresponding author. Tel.: +34 959219798

Fax: +34 959 9219265; E-mail: manuel.contreras@dfa.uhu.es

(C) 2018 International Association for Sharing Knowledge and Sustainability

DOI: $10.5383 /$ ijtee.16.02.006 
provide ilmenite of higher $\mathrm{TiO}_{2}$ content, including altered ilmenite $\left(60 \%-75 \% \mathrm{TiO}_{2}\right)$, leucoxene $\left(76 \%-90 \% \mathrm{TiO}_{2}\right)$ and rutile $\left(95 \% \mathrm{TiO}_{2}\right)$ [7].

On the other hand, in alluvial sediments, ilmenite alters and $\mathrm{Fe}$ is partially leached in a continuous process going to pseudorutile $\left(\mathrm{Fe}_{2} \mathrm{Ti}_{3} \mathrm{O}_{9}\right)$ and leucoxene [8]. For that reason, titanium and iron content in the ilmenite may vary significantly, as it can be present in its primary stoichiometric form $\left(\mathrm{FeTiO}_{3}\right)$ or as weathered ilmenites and mixtures of both types. The weathered ilmenite is the result from the oxidation and partial dissolution by ground water of the iron. In this sense, the progressive removal of this iron by leaching; and the relative increase in the concentration of impurity elements alters the original ilmenite [9]. The $\mathrm{TiO}_{2}$ content can even exceed the $60 \%$ when the ore is altered to leucoxene, which is a mixture of rutile or anatase amorphous $\mathrm{TiO}_{2}$ and iron oxides. In addition, ilmenite usually contains some impurities like monazites, spinel, quartz and zircon, as minority mineral [10]. These impurities have a concentration process, remaining associated to the co-products or wastes of the industrial process. Therefore, recovery these minerals prior the industrial process is economic and environmental interesting.

In this sense, we have carried out an exhaustive characterisation of the ilmenite used in a titanium-dioxide industry, located in the province of Huelva (Spain), which produces pigments by applying the sulphate process. In this factory, the first residue obtained, known as sludge (or undissolved mud), are enriched in titanium dioxide (around $50 \%$ of $\mathrm{TiO}_{2}$ ), which represent $5 \%$ of the total Ti present in the raw material [11,12]. Also, this sludge is formed by several refractory mineral phases as unattached ilmenite, rutile, quartz and zircon coming from the commercial ilmenite used in the industrial process $[13,14]$. Currently, there are no economic commercial applications for the sludge Therefore, to recovery these mineral phases for subsequent marketing in different fields would be a possibility environmentally and economically appropriate.

In addition, this waste is stored in a controlled landfill repository, which implies a cost of about three million euros for its final elimination (including transportation costs). This waste could be reduced by the optimization of the process and a significant improving in the competitiveness of this industry will be produced. In this context, the process optimization is a correct environmental solution to the disposal and economical improving by reducing waste and marketing the minerals.

In view of the above, the main objective of this paper is to specify the physico-chemical characterization of the different mineralogical phases presents in the raw material used in $\mathrm{a} i O_{2}$ pigment industry, and to apply this information in the optimization of the industrial process. Consequently, the isolation and recovery the undissolved mineral phases and other impurities before to entry in the industrial process.

\section{Materials and methods}

\subsection{Materials}

The samples of raw material ("commercial ilmenite named ILUKA") were provided for use in this study by the titanium dioxide production plant $12 \mathrm{~km}$ from the city of Huelva. Five sampling campaigns were organised during a period of 1 month, taking place every 6 days. The objective was to analyse the possible temporal variability in the characteristics of the materials, and to obtain representative samples to be used in the new manufactured materials. After collection, the raw materials were dried at $105^{\circ} \mathrm{C}$.

\subsection{Methods}

The identification of the mineral phases was performed by the $\mathrm{XRD}$ technique (X-ray diffraction) in a Bruker diffractometer (model D8 Advance), using $\mathrm{Cu} \mathrm{K} \alpha$ radiation operating at a current of $30 \mathrm{~mA}$, and a voltage of $40 \mathrm{kV}$. Data were recorded in the $5-70^{\circ} 2 \Theta$ range (step size $0.019736^{\circ}$ and $0.5 \mathrm{~s}$ duration for each step).

According the mineralogical composition of the raw material was carried out the most efficient tuning parameters using a Frantz magnetic barrier separator type LB-1 for concentrating and refining each mineral phase present in our commercial ilmenite. This technique is based on the magnetic susceptibility in the presence of a magnetic field, adapting the intensity, and the incline chute angles, side tilt and forward slope [16].

Then, the fractions obtained were characterized by determining the mineralogical composition (XRD). Moreover, major elements were determined by an inductively coupled plasma optical emission spectrometry (ICP-OES) by using a Jobin Yvon ULTIMA 2 system. Trace elements were determined by Inductively Coupled Plasma Mass Spectrometry (ICP-MS) by using an HP4500® system, at the Research Central Services, in the University of Huelva, after the total dissolution of the samples and its posterior dilution and adaptation for their introduction in the system in $2 \%$ nitric acid, following the method of fusion studied by other authors [17]. Finally, the morphology, microscopic structure and microscopic composition of the mineral fractions were carried out by SEM analyses using a JEOL JSM-5410 system, working at $20 \mathrm{kV}$. It has a backscattered electron detector (BSE), by Tetra Link of Oxford, and a dispersive X-ray spectrometer for EDS.

\section{Results and discussion}

The mineralogical composition of the ore (commercial ilmenite), obtained by XRD, is characterised by a high concentration of ilmenite $\left(\mathrm{FeTiO}_{3}\right), 70 \pm 6 \%$, compensated by the presence of pseudorutile $\left(\mathrm{Fe}_{2} \mathrm{Ti}_{3} \mathrm{O} 9\right), 20 \pm 3 \%$. Also, is presents, rutile, $(7 \pm 1 \%)$ in accordance with previous results [11-14].

\subsection{Tuning method for mineral separation}

After an exhaustive literature review, the authors don not find a specific technique and methodology to isolate each mineral phases in the ilmenite ore. In general the papers present a wide range of adjustment parameters among the methods, but the most efficient technique is the magnetic separation $[18,19]$. For this reason, it was necessary to tune up a magnetic separation process, depending on two parameters, intensity (in view of the magnetic susceptibility of each mineral) and angles in the incline chute in the separator (side tilt and forward slope). The minerals can be mainly classified according to the type of magnetism and magnetic susceptibility $\left(\chi_{\mathrm{m}}\right)$ (ilmenite: ferromagnetism and $\chi_{\mathrm{m}}>$ 1 ; pseudorutile and rutile: paramagnetism and $\chi_{\mathrm{m}} \approx 10^{-6}$; zircon and quartz: diamagnetism and $\chi_{\mathrm{m}} \approx-10^{-6}$ ) [20].

To carry out the magnetic separation prior the industrial process, samples were firstly sieved obtaining the thick material (particle size $>250 \mu \mathrm{m}$ ), which was again grounded and completely sieved smaller than $250 \mu \mathrm{m}$. This milling involves no added 
economic cost, since the raw material is grounded with a particle size $<70 \mu \mathrm{m}$ before entering the industrial process [2]. The magnetic separation method was applied on the fraction between 125 to $250 \mu \mathrm{m}$, as recommended the Frantz's manual [18]. The fine material (FF) with size smaller than $125 \mu \mathrm{m}$ and approximately a $7 \%$ of the total RM, was declined for Frantz separation.

In addition, it is necessary to remove the high magnetic fraction prior Frantz method (magnetic separation) was applied (Fig. 1). According to the manual, the most magnetic fraction was rejected to avoid interferences, because its high magnetic susceptibility could influence in the behaviour of another particles [18]. The highest magnetic material was obtained by a hand magnet form the HMF (Hand Magnet Fraction), around a $5 \%$ of the total RM. Besides, the magnetic material obtained in first separation (approximately a $16 \%$ of the total RM) was saved and later mixed with the ilmenite fraction (IF), due to it is composed mostly of ilmenite. Furthermore, the magnetic material obtained in second separation is the fraction called "ilmenite fraction" (IF). The rest of the sample was processed according the third separation (Fig. 1), giving the last two fractions, the magnetic material is called "rutile fraction" (RF) and the non-magnetic as "zircon fraction" (ZF).

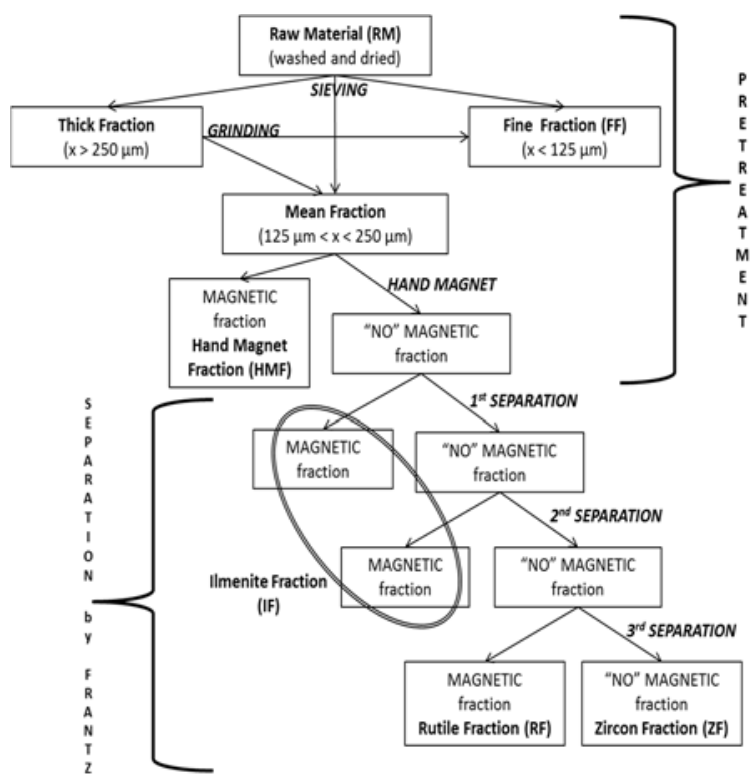

Fig. 1. General process by Frantz magnetic separation

Previously, an optimisation in the use of Frantz was performed according several tests used setting as in the bibliography (test $1-4$ ) and test 5 was proposed by us (table 1 ), where the intensity, side tilt and forward slope were changed in order to achieve the optimum group of parameters. Agreeing to the mineral composition, the most efficient parameters correspond with test 5 (Table 2), where the ilmenite concentration is around $89 \%$. In addition, test 5 also shows the most efficient in the separation of rutile and zircon, with 58 and $62 \%$, respectively. The other fractions obtained present a wide variety and concentrations of minerals, due to the presence of minerals with similar values of magnetic susceptibility. As explained below, the deposits that may have some mineral species in nature can alter the results, i.e., minerals that are usually diamagnetic may appear as paramagnetic under certain conditions of alteration.
Table 1. Posed setup parameters. I: Intensity applied (A), S: side tilt $\left({ }^{\circ}\right)$, F: forward slope $\left({ }^{\circ}\right)$.

\begin{tabular}{|c|c|c|c|}
\hline Test & $1^{\text {st. }}$ Separation & $2^{\text {nd. }}$ Separation & $3^{\text {rd. Separation }}$ \\
\hline 1 & $\mathrm{I}=0.05 ; \mathrm{S}=30 ; \mathrm{F}=10$ & $\mathrm{I}=0.4 ; \mathrm{S}=30 ; \mathrm{F}=10$ & $\begin{aligned} \mathrm{I}= & 1.4 ; \mathrm{S}=30 ; \mathrm{F}=10 \\
& +\mathrm{S}=10 ; \mathrm{F}=5\end{aligned}$ \\
\hline 2 & $\mathrm{I}=0.1 ; \mathrm{S}=25 ; \mathrm{F}=15$ & $\mathrm{I}=0.4 ; \mathrm{S}=25 ; \mathrm{F}=15$ & $\mathrm{I}=1.4 ; \mathrm{S}=25 ; \mathrm{F}=15$ \\
\hline 3 & $\mathrm{I}=0.1 ; \mathrm{S}=25 ; \mathrm{F}=10$ & $\mathrm{I}=0.3 ; \mathrm{S}=25 ; \mathrm{F}=10$ & $\mathrm{I}=1.2 ; \mathrm{S}=25 ; \mathrm{F}=10$ \\
\hline 4 & $\mathrm{I}=0.05 ; \mathrm{S}=15 ; \mathrm{F}=10$ & $\mathrm{I}=0.2 ; \mathrm{S}=15 ; \mathrm{F}=10$ & $\mathrm{I}=1.2 ; \mathrm{S}=15 ; \mathrm{F}=10$ \\
\hline 5 & $\mathrm{I}=0.05 ; \mathrm{S}=12 ; \mathrm{F}=15$ & $\mathrm{I}=0.2 ; \mathrm{S}=12 ; \mathrm{F}=15$ & $\mathrm{I}=1 ; \mathrm{S}=12 ; \mathrm{F}=15$ \\
\hline
\end{tabular}

\subsection{Mineral characterization}

Fine fraction, $(\mathrm{FF}),<125$ microns, is formed by several mineral phases as rutile, pseudorutile, ilmenite, zircon, quartz and monazite $(<5 \%)$. On the other hand, the hand magnet fraction (HMF), shown a mineralogical compositions of ilmenite and magnetite $\left(\mathrm{Fe}_{3} \mathrm{O}_{4}\right)$ with 30 and $70 \%$ respectively, which are the minerals with the highest magnetic susceptibility. Ilmenite fraction (IF) present the characteristic peaks of ilmenite and pseudorutile (Fig. 2.A) [21], with 89 and $11 \%$ respectively (see table 2 ; test 5 ). The rutile fraction (RF) corresponds to a mix of minerals such as rutile $(58 \%)$, zircon $(36 \%)$ and a minimal presence of pseudorutile. Also, in this fraction a minimum amount of spinel $(<5 \%)$ is detected (Fig. 2.B). Moreover, the study of the non-magnetic fraction, called "zircon fraction" (ZF), shows the characteristic peaks of the three main mineral phases, zircon $(62 \%)$, but a low content of quartz $(22 \%)$ and rutile $(16 \%)$ (Fig. 2.C).

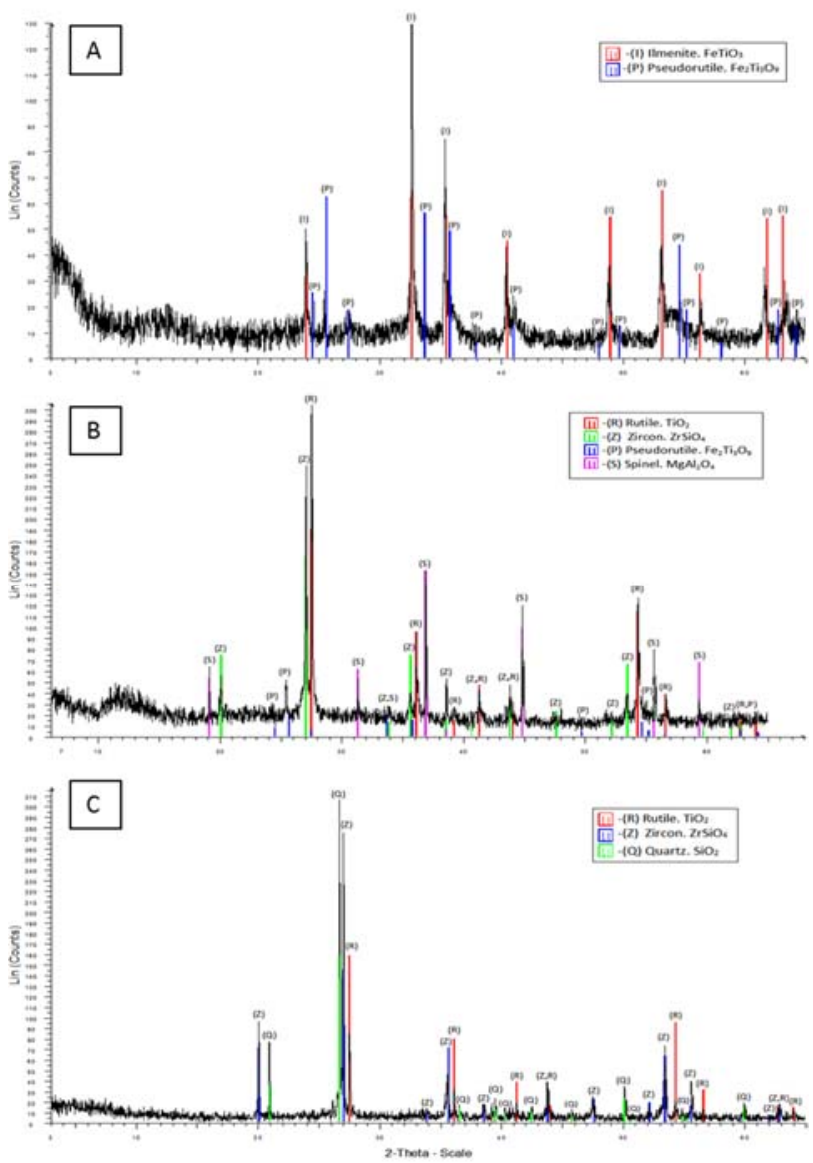

Fig. 2. Representative DRX spectrum: (A) ilmenite fraction; (B) rutile fraction; $(C)$ zircon fraction 
Finally, it is important to note that these mineral phases remain in the un-dissolved mud, obtained in the industrial process, where several species are observed: ilmenite and rutile, with a percentage of $22 \%$ and $34 \%$, respectively, and additionally zircon $(12 \%)$, quartz $(13 \%)$, and $\mathrm{Fe}$ and $\mathrm{Ti}$ oxides $(18 \%)$ $\left(\mathrm{Fe}_{3} \mathrm{Ti}_{3} \mathrm{O}_{10}\right)[12,13]$. The high percentage of rutile and the detection and quantification in the mud of the aforementioned mineral phases (zircon and quartz) cannot be considered as surprising, since all of these species are insoluble in sulphuric acid [2]. Therefore, with this previous magnetic separation, these insoluble mineral phases can be removed of the final mud.

Table 2. Mineralogical composition (\%) crystalline phase by XRD for each fraction obtained by the Frantz after each separation in the different test

\begin{tabular}{ccccccccccccc}
\hline \multicolumn{1}{c}{} & \multicolumn{1}{c}{ Ilmenite } & \multicolumn{4}{c}{ Ritile } & \multicolumn{4}{c}{ Zircon } \\
Test & I & Ps & I & S & Ps & R & Z & Q & R & Z & Q \\
1 & 61 & 39 & 24 & N.D. & 6 & 26 & 27 & 17 & 53 & 33 & 14 \\
2 & 62 & 38 & 21 & N.D. & 7 & 27 & 27 & 18 & 57 & 25 & 18 \\
3 & 72 & 28 & 15 & N.D. & 8 & 31 & 27 & 19 & 45 & 38 & 17 \\
4 & 64 & 36 & 12 & N.D. & 8 & 32 & 30 & 18 & 40 & 41 & 19 \\
5 & 89 & 11 & N.D. & $<5$ & 6 & 58 & 36 & N.D. & 22 & 62 & 16 \\
\hline
\end{tabular}

*I (Ilmenite; Ps (Pseudorutile); S (Spinel); R (Rutile); Z (Zircon); Q (Quartz)

**N.D. Not Detected

\subsection{Major and trace elements}

The chemical analysis by ICP-OES of major and trace elements is shown in Table 3. RM contain mainly two major elements, Ti and $\mathrm{Fe}(37 \%$ and $36 \%)$, as expected, because of typical ilmenite deposit contains about $45-65 \%$ of $\mathrm{TiO}_{2}$ and around $50 \%$ of iron, given as $\mathrm{FeO}$ [11-14,22]. In addition, lower concentrations of $\mathrm{Si}$, $\mathrm{Mn}$, and $\mathrm{Zr}$ with a concentration around 1.6, 1.4 and $0.07 \%$ respectively are obtained. Also, it presents trace elements like $\mathrm{La}, \mathrm{Co}$ and $\mathrm{Ce}\left(217,51\right.$ and $396 \mathrm{mg} \mathrm{kg}^{-1}$, respectively) as impurities associated to pseudorutile phase. This fact is not unexpected; because it is documented, that pseudorutile presents higher levels of associated trace elements. For example, elements such as $\mathrm{Mn}, \mathrm{Ce}$, and $\mathrm{Co}$ may substitute $\mathrm{Fe}$ or $\mathrm{Ti}$ in the original ilmenite lattice, while elements like $\mathrm{Al}, \mathrm{Si}, \mathrm{Th}, \mathrm{P}$ and $\mathrm{Cr}$ are commonly incorporated into the ilmenite grains during the chemical weathering [23]. For example, the Australian ilmenite concentrates are invariably contaminated with chrome-bearing spinel grains, which are difficult to remove using standard physical separation methods [24].

The FF values are similar to the RM (raw material), except the high concentration of $\mathrm{P}$ and $\mathrm{Ce}$, approximately a factor 3 and 2 respectively. These data have been supported further by SEM studies, because appear small particles of monazite $(\mathrm{Ce}(\mathrm{Ce}, \mathrm{La}$, $\mathrm{Pr}, \mathrm{Nd}, \mathrm{Th}$, and $\mathrm{Y}) \mathrm{PO}_{4}$ ). HMF and IF show similar values to RM in most of the major elements, but in iron, HFM presents the highest concentrations with $52 \%$ of Fe. According to the mineralogical analysis, because it presents the most magnetic mineral (ilmenite and magnetite), composed mainly by Fe. On the hand, RF presents a lower concentration of $\mathrm{Fe}(2 \%)$ due to the presence of pseudorutile, observed by XRD, table 2.Taking into account the Figure 2.B, RF presents a new mineralogical phase, called spinel $\left(\mathrm{MgAl}_{2} \mathrm{O}_{4}\right)$, and logically presents the highest concentration of $\mathrm{Al}$, and $\mathrm{Mg}$ with 7.6 and $3.5 \%$, respectively, a factor 10 higher than in the RM. In addition, due to contain certain quantity of zircon mineral, it is no surprising the high concentration of $\mathrm{Zr}(2.1 \%), 30$ times upper than in RM sample. ZF fraction shows the lowest concentration in $\mathrm{Fe}$ $(0.46 \%)$, because not present mineral phases containing $\mathrm{Fe}$, as ilmenite or pseudorutile. Nevertheless, it presents the highest concentration of $\mathrm{Zr}(4.4 \%), 60$ times upper than RM. Also shown $11 \%$ of $\mathrm{Ti}$, being congruent with its mineralogical composition. Moreover, ZF has the smallest concentration in $\mathrm{Mn}$, a factor 100 than in the RM, due this element is associated to the presence of ilmenite [25]. Also, uranium and thorium are accumulated mainly in this fraction due to the high concentration of rutile and the presence of monazite, 90 and $160 \mathrm{mg} \mathrm{kg}^{-1}$ for $\mathrm{U}$ and Th and factors 10 and 2 higher than RM [2]. Finally, ZF and $\mathrm{RF}$ are around a $2 \%$ of the total RM. Taking into account, the quantity of raw material used in the factory of Huelva is 142000 $t$ of commercial ilmenite, making up $2840 \mathrm{t}$ of both fractions, RF and ZF. Therefore, according the composition shown in table 3, around of $1200 \mathrm{t}$ of $\mathrm{Ti}$ and $150 \mathrm{t}$ of $\mathrm{Zr}$ can be remove of the residue obtained in the industrial process, undissolved mud [1114].

Table 3. Chemical composition of the analysed samples by ICPOES for the major elements (wt. \%) and by ICP-MS for the trace elements $(\mathrm{mg} / \mathrm{kg})$

\begin{tabular}{|c|c|c|c|c|c|c|}
\hline & $\mathrm{RM}$ & FF & HMF & IF & $\mathrm{RF}$ & $\mathrm{ZF}$ \\
\hline \multicolumn{7}{|c|}{ MAJOR ELEMENTS } \\
\hline $\mathrm{Fe}$ & 36 & 40 & 52 & 38 & 2.0 & 0.46 \\
\hline $\mathrm{Ti}$ & 37 & 41 & 39 & 39 & 32 & 11 \\
\hline $\mathrm{Al}$ & 0.64 & 0.63 & 1.4 & 0.43 & 7.6 & 1.3 \\
\hline $\mathrm{Si}$ & 1.6 & 1.0 & 2.1 & 1.3 & 1.4 & 1.2 \\
\hline $\mathrm{Mg}$ & 0.31 & 1.4 & 0.81 & 0.22 & 3.5 & 0.11 \\
\hline $\mathrm{Mn}$ & 1.4 & 1.3 & 1.3 & 1.8 & 0.03 & 0.01 \\
\hline $\mathrm{Zr}$ & 0.07 & 0.22 & 0.04 & 0.03 & 2.1 & 4.4 \\
\hline \multicolumn{7}{|c|}{ TRACE ELEMENTS } \\
\hline As & 37 & 42 & 18 & 39 & 161 & 22 \\
\hline $\mathrm{Cr}$ & 464 & 805 & 690 & 420 & 1000 & 301 \\
\hline $\mathrm{Sr}$ & 476 & 415 & 430 & 512 & 604 & 416 \\
\hline $\mathrm{P}$ & 210 & 730 & 260 & - & 432 & 403 \\
\hline $\mathrm{V}$ & 960 & 1089 & 1200 & 1000 & 1000 & 800 \\
\hline Co & 51 & 18 & - & 52 & 11 & 2.7 \\
\hline $\mathrm{Pb}$ & 176 & 20 & - & 128 & 100 & 22 \\
\hline $\mathrm{Zn}$ & 190 & 100 & 90 & 2.0 & 440 & 60 \\
\hline $\mathrm{La}$ & 217 & 12 & - & 67 & 56 & 6.9 \\
\hline Th & 80 & 101 & 45 & 56 & 162 & 17 \\
\hline $\mathrm{U}$ & 7.7 & 6.8 & 5.2 & 5.4 & 90 & 33 \\
\hline $\mathrm{Ce}$ & 396 & 601 & - & 122 & 124 & 16 \\
\hline
\end{tabular}

*RM (Raw Material); FF (Fine Fract.); HMF (High Magnetic Fract.); IF (Ilmenite Fract.); RT (Rutile Fract.); ZF (Zircon Fract.)

\subsection{Scanning electron microscopy (SEM)}

A representative SEM image for the IF can be observed in Figure 3. EDX spectrum reveals the grains contain major elements as iron and titanium, agree XRD data, showing the typical composition of ilmenite particle $\left(\mathrm{FeTiO}_{3}\right), 47 \%$ of $\mathrm{FeO}$ and $53 \%$ of $\mathrm{TiO}_{2}$ [26]. A detailed SEM analysis allows us to know the morphology, formed mainly by ilmenite particles with pseudotabular morphologies [22]. Other ilmenite grains present rhombohedra and tabular morphology, and very uniform composition (Fig. 3.A), being $\mathrm{Ti}$ and $\mathrm{Fe}$ the main elements with 
traces of Mn. On the other hand, the particle "B" is formed by three-quarters of titanium and a quarter of iron (Fig. 3.B), in agreement with a mineral known as pseudorutile $\left(\mathrm{Fe}_{2} \mathrm{Ti}_{3} \mathrm{O}_{9}\right)$ $[8,27]$. Finally, extremely shiny microscopic particles were detected in a low proportion (Fig. 3.C). These particles give a typical heavy metal mineral composition $(\mathrm{Nb}, \mathrm{Ce}$, and $\mathrm{Th})$, corresponding to the rare earth metals: cerium, lanthanum and thorium, associated with a mineral phosphate group, called monazite [28].
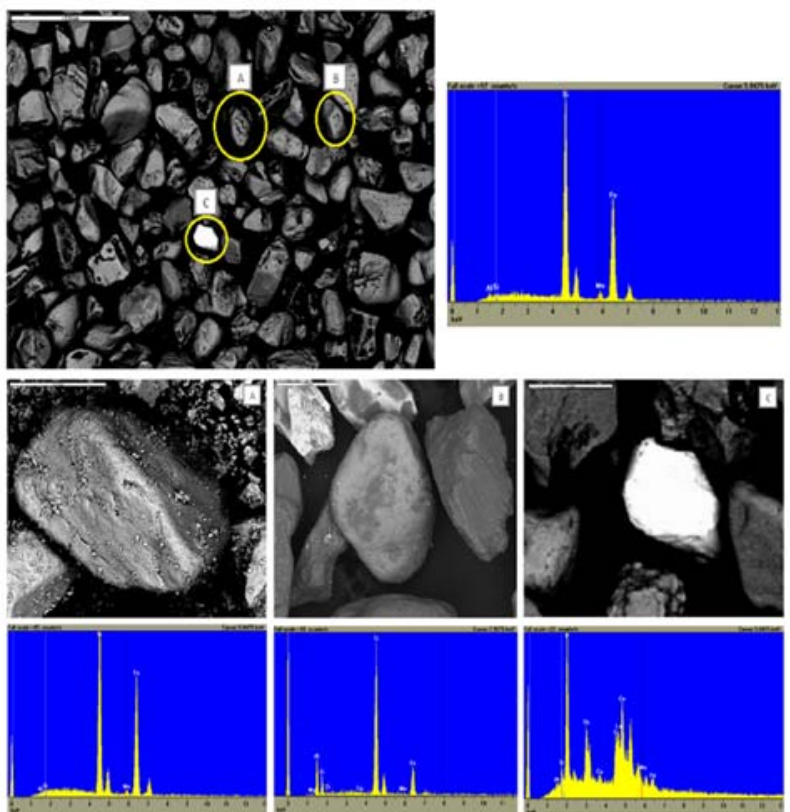

Fig. 3. Representative SEM (BSE) image and EDX of the IF (A) ilmenite (B) pseudorutile (C) monazite

RF shows a high heterogeneity (Fig. 4) in accordance with the morphology. In the EDX spectrum, grains mainly contain $\mathrm{Zr}, \mathrm{Si}$, $\mathrm{Ti}$ and $\mathrm{Al}$, corresponding to zircon $\left(\mathrm{ZrSiO}_{4}\right)$, rutile $\left(\mathrm{TiO}_{2}\right)$ and spinel, respectively. In addition, low iron concentration is present, consistent with the presence of pseudorutile. A specific analysis by SEM-EDX, shown that figure 4.A is majority composed by titanium, with a remainder of iron, according to the typical composition of rutile $\left(>90 \mathrm{wt} . \% \mathrm{TiO}_{2}\right)$ [29]. Smaller particles (around $150 \mu \mathrm{m}$ ) are also observed, with a high heterogeneous morphology and composition (Fig. 4.B), containing mainly aluminium and small proportions of silicon, titanium and iron content. This figure shows a typical spectrum of aluminium silicate, corresponding with the minerals group known as spinel [24]. In this fraction appears, as in the ilmenite fraction (IF), the presence of pseudorutile (particle C). Moreover, another mineral is observed, particle $\mathrm{D}$, containing major elements as zirconium and silicon, with similar values to the typical particle of zirconium silicate $\left(\mathrm{ZrSiO}_{4}\right), 67 \%$ to $33 \%$ of $\mathrm{SiO}_{2}$ and $\mathrm{ZrO}_{2}$ [30].

Figure 5 shows a representative SEM and EDX spectrum corresponding to the ZF (zircon fraction). The morphology is quite complex according SEM image. In relation with EDX, particles contain mainly silicon and titanium with smaller proportions of zirconium and aluminium. For example, particle "A" presents as major elements zirconium and silicon, compatible with the presence of zircon mineral, $\left(\mathrm{ZrSiO}_{4}\right)$, while particle B composed solely of silicon, corresponds to quartz $\left(\mathrm{SiO}_{2}\right)$. Rutile particles are also detected (particle $\left.\mathrm{C}\right)$.
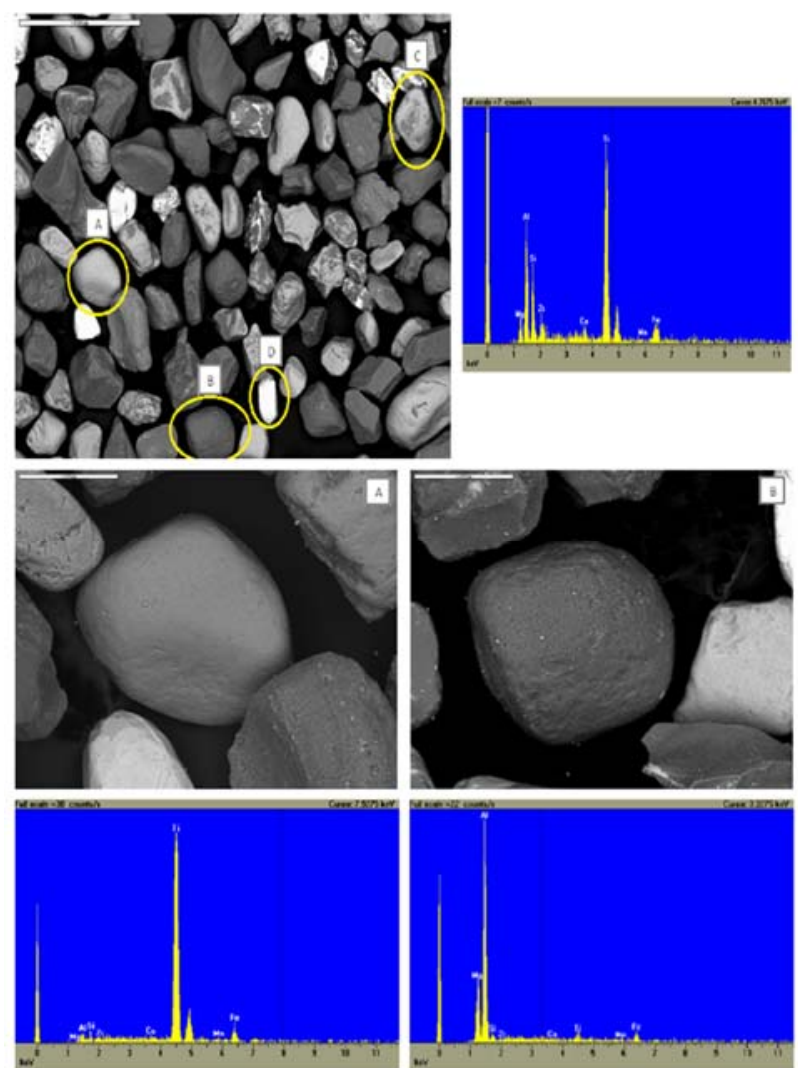

Fig. 4. SEM (BSE) image of the RF and EDX spectrum. (A) rutile particle. (B) spinel particle
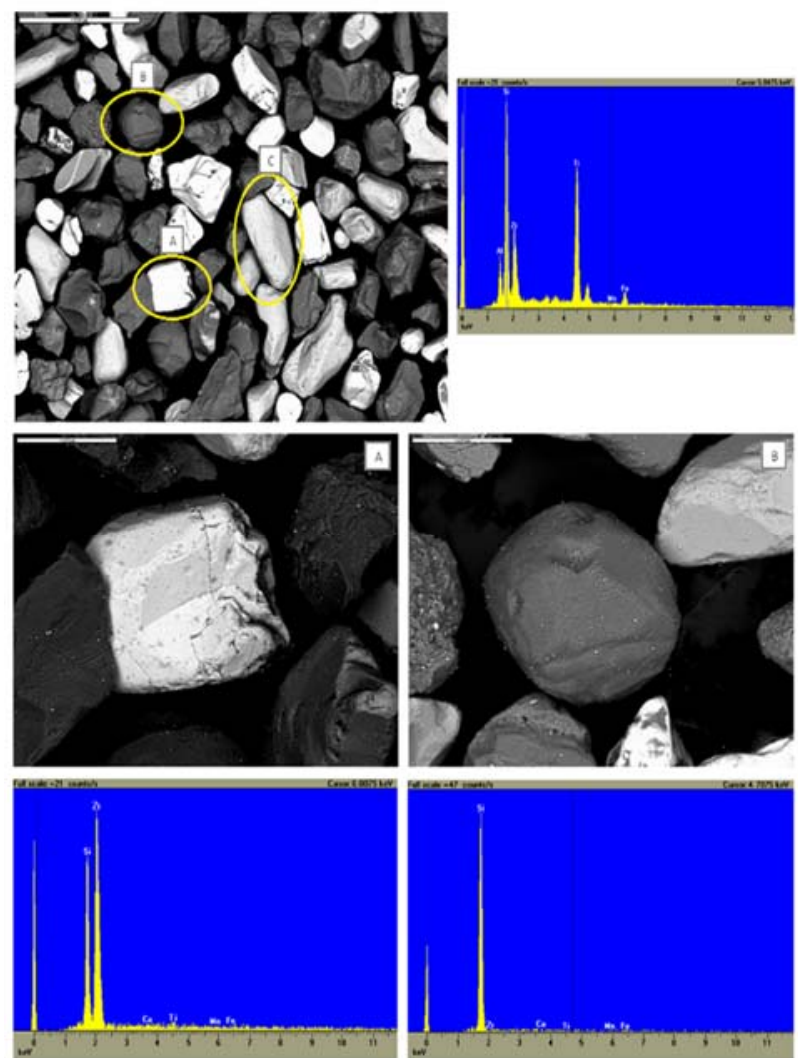

Fig. 5. SEM (BSE) image and EDX spectrum of the ZF. (A) zircon particle. (B) quartz particle 
Due to the complexity of the different phases, a polished probe of $33 \mathrm{~mm}$ (figure 6) was prepared with RM (raw material) sieved between 125 and 250 microns. These analyses were made to (a) confirm the complete range of alteration products and to establish the chemical composition of each phase, (b) determine the major element constituents, and (c) study the particles in the surface and inside.

The sample is predominantly composed by ilmenite and its alteration products, with a continuous transition from pure ilmenite, through intermediate alteration phases, such as leached ilmenite, pseudorutile and leached pseudorutile to secondary rutile [31]. Also, there are many types and shapes of particles, where some of them reveal its internal shape, figure 6.A-C. A separate study of each different areas, dark (zone 1) and shiny (zone 2) was conducting. In addition, a third zone (grey area) appears in some cases, demonstrating that the grains contain different concentrations of iron, titanium, aluminium and silicon in each area. The difference in iron concentration occurs due to the weathering of the ore, which leaches out the iron from the ilmenite lattice leaving a Ti rich region [32].

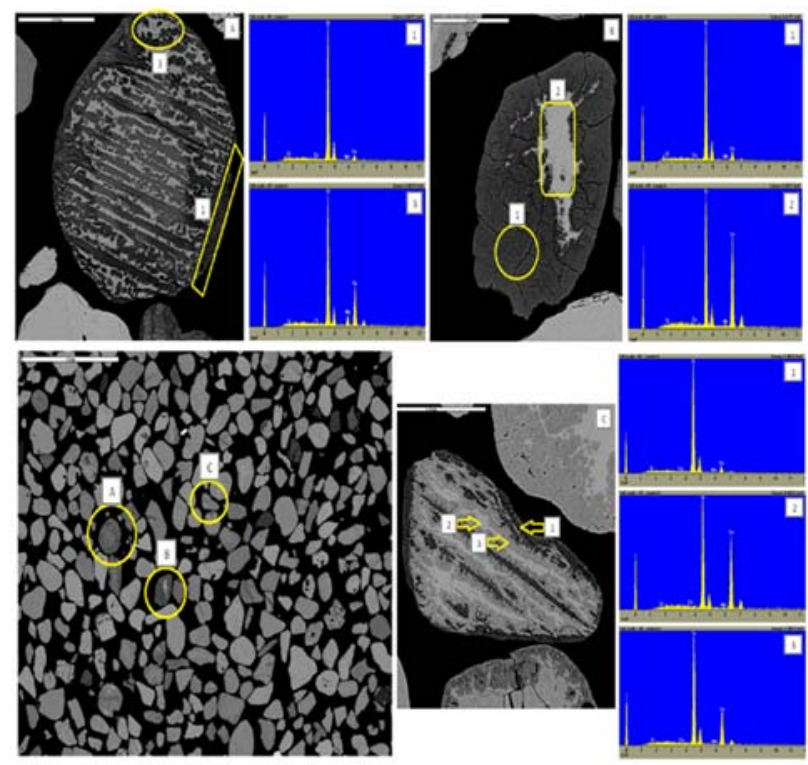

Fig. 6. SEM (BSE) image of the RM polished probe. SEM-EDX of (A) particle A. (B) particle B. (C) particle $C$

Furthermore, zircon can also vary its magnetic susceptibility depending on the composition, according to its presence in both RF (rutile fraction) as ZF (zircon fraction). Pedogenic index presented by zircon, leads us to assume it is weather-proof. However, this assumption has not tested, features appear to be evidence of wear in zircon (Fig. 7.A), produced by the mobility of $\mathrm{Zr}$. This evidence is similar to other researchers [33]. Besides, zircon can present impurities by the intrusion of another mineral, figure 7.B. Zircon is formed mainly by zirconium and silicon, zone 1 (light grey) and presents an impurity inside the particle, zone 2 (dark grey). This impurity is formed by titanium and iron, but the iron content is higher than a typical ilmenite particle [34,35]. As explained before, diamagnetic mineral may appear as paramagnetic under certain conditions of alteration, hindering their total isolation.
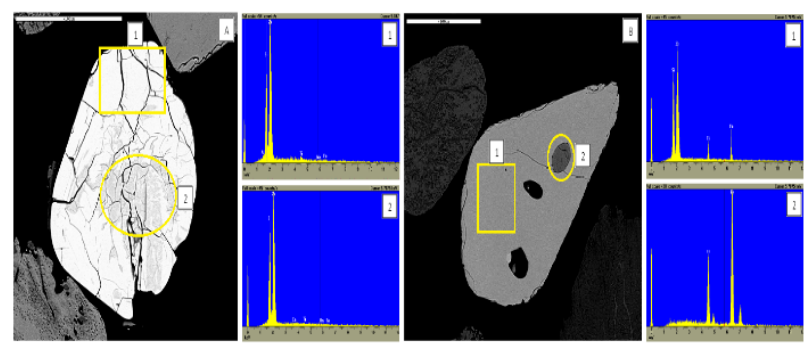

Fig. 7. SEM-EDX analysis of: (A) zircon particle; (B) zircon particle

\subsection{Environmental and economical implications}

According the different fractions obtained during this procedure, some minerals with economical interest are isolated and can be removed prior the industrial process. So, taking into account, the 142000 tons of raw material (RM) used per year in the factory of Huelva [11-14]. Fine fraction, 7\% of total RM, presents mineral like monazite $(<5 \%)$, making up 9940 tons of FF and around of 497 tons of monazite. Furthermore, the hand magnet fraction (HMF), about $5 \%$ of the total RM, is formed mostly by magnetite (70\%), making up 7100 tons of HMF and 4970 tons of magnetite. Finally, from RF and ZF, a $2 \%$ of the total RM, making up 2840 tons of both fractions. Therefore, around of 60 tons of spinel and 923 tons zircon can be obtained from both fraction, respectively. On the other hand, the $\mathrm{Zr}$ and Rutile fraction can be mixed and subsequently treated with $\mathrm{HCl}$ to extract the remaining $\mathrm{Ti}$ or directly used as raw material in the process via chloride. The zircon and spinel are not affected by the acid attack achieving the separation of these elements from the removed $\mathrm{Ti}$.

Also, in this procedure about of $86 \%$ of the RM forms the Ilmenite fraction, which around $89 \%$ is formed by ilmenite mineral. It makes up 122120 tons of IF and approximately 108687 tons of pure ilmenite.

In the experimental protocol proposed in this study, with some adjustments in this separation process, as well as with the use of other ore separation technologies, most of the mineral can be isolate prior to the industrial process. Avoiding these fractions minerals, which cannot be dissolved in the digestion step, come in the industrial process and therefore in the final residue (undissolved mud). The magnitude of this generated waste is around 30,000 tons per year, which until now have not had any use, and therefore it is disposed of in an authorized waste repository $[11,13]$. Therefore, this procedure would not only help to optimize the industrial process but could also reduce the potential risk of pollution from the undissolved mud stack to the environment.

\section{Conclusion}

The general results obtained in this work were firstly to develop a magnetic method to isolate the mineral phases in the titanium dioxide industry ore (commercial ilmenite), being test number 5 the set parameters more efficiency according separation, see table 2. The results obtained with our "setting" are better than these obtained following the Frantz methodology (test 1-4).

Secondly, physico-chemical characterization of each mineral from the ore was carried out. It is composed of ilmenite and its alteration products (ilmenite unchanged, leached ilmenite, pseudorutile, leached pseudorutile and rutile). Only three 
different diffraction patterns can be detected among all the different phases of transformation ilmenite, pseudorutile and rutile, by XRD. Leached ilmenite and leached pseudorutile are transitional metastable phases and show the same structure as the respective parent minerals, ilmenite and pseudorutile, until the structure breaks down completely. According SEM result, these particles were originally pure particles of ilmenite, due to the weathering fracture lines have formed inside the grains. Subsequently, located in these fractures, occurs an alteration and transformation of the original mineral, appearing different transformation stages. With the progressive loss of iron, it is transformed from ilmenite (shiny areas), to pseudorutile (intermediate areas) and lastly with the total loss, to rutile (dark areas).

In more detail, our results indicate that the main raw material used (ilmenite) has a variable mineralogical and elemental composition. The concentrate contains small amounts (1.5-2\%) of others minerals potentially economics (monazite is associated with the fine fraction, spinel with the rutile fraction, quartz with the zircon fraction, etc.). The minerals contained in the ilmenite are not pure (physical mixes of them), implies the fact that it is impossible to isolate $100 \%$ the different mineral fractions initially present in the raw material.

According the different fractions obtained during this procedure, some minerals with potential economic interest can be removed from the ore prior the industrial process, like monazite in FF, magnetite in HMF, spinel in RF, and zircon in ZF. Obtaining an ilmenite ore mostly formed by ilmenite mineral. Furthermore, this procedure optimizes the industrial process and could also reduce the waste generation (undissolved mud) and the potential environment risk.

\section{Acknowledgments}

This research has been partially supported by the Government of Andalusia' s Project "Characterization and modelling of the phosphogypsum stacks from Huelva for their environmental management and control" (Ref.: RNM-6300). Dr. M. Contreras expresses her gratitude for the contract by The Fellowship Training Program of the University Teaching Staff, reference AP2010-2746, financed by the Spanish Ministry of Education, Culture and Sport (MECD).

\section{References}

[1] Zhang W, Zhu Z, Cheng CY. A Literature Review of Titanium Metallurgical Processes. Hydrometallurgy 3022;108:177-188. https://doi.org/10.1016/j.hydromet.2011.04.005

[2] McNulty, GS. Production of Titanium Dioxide. Plenary Lecture. NORM V International Conference, Sevilla. 2007.

[3] Rosebaum, J.B. (1982) Titanium Technology Trends. JOM 1982;34:76-80

[4] Stwertka, A. Guide to the Elements. Revised Edition, Oxford University Press, London. 1998.

[5] Williams, V.A. WIM 150 Detrital Heavy Mineral Deposit. In: Hughes, F.E., Ed., Geology of the Mineral Deposits. 1990.

[6] Adams, R. The World Market for TiO2 Feedstocks. Minerals Industry International, 9-14. 1994-
[7] Barksdale, J. Titanium, Its Occurrence, Chemistry, and Technolog. 2nd Edition, The Roland Press Company, New York. 1996.

[8] Mucke A, Bhadra Chaudhuri JN. The continuous alteration of ilmenite through pseudorutile to leucoxene. Ore Geology Reviews, 1991;6(1):2544.

[9] Pownceby, MI. Alteration and associated impurity element enrichment in detrital ilmenites from the Murray Basin, southeast Australia: A product of multistage alteration, Aust. J. Earth Sci. 2010;57(2):243-258. http://dx.doi.org/10.1080/08120090903521705

[10] Gupta CK, Krishnamurthy N. Extractive Metallurgy of Rare Earths. CRC Press, London. 2004.

[11] Contreras M, Gázquez MJ, García-Díaz I, Alguacil FJ, López FA, Bolívar JP. Valorisation of waste ilmenite mud in the manufacture of sulphur polymer cement. J. Environ. Manage. 2013;128:625-630. https://doi.org/10.1016/i.jenvman.2013.06.015

[12] Contreras M, Martín MI, Gázquez MJ, Romero M, Bolívar JP. Valorisation of ilmenite mud waste in the manufacture of commercial ceramic. Constr. Build. Mater. 2013;72:31-40. https://doi.org/10.1016/j.conbuildmat.2014.08.091

[13] Gázquez MJ, Bolívar JP, García-Tenorio R, Vaca F. Physicochemical characterization of raw materials and co-products from the titanium dioxide industry. J. Hazard. Mater. 2009;166:1429-1440. https://doi.org/10.1016/j.jhazmat.2008.12.067

[14] Gázquez MJ, Mantero J, Bolívar JP. Physico-chemical and radioactive characterization of $\mathrm{TiO} 2$ undissolved mud for its valorization. J. Hazar. Mater. 2011;191:269-276. https://doi.org/10.1016/j.jhazmat.2011.04.075

[15] Gázquez MJ, Bolívar JP, Garcia-Tenorio R, Vaca F. A Review of the Production Cycle of Titanium Dioxide Pigment. MSA 2014;5:441-458. DOI:10.4236/msa.2014.57048

[16] Augusto PA, Augusto P, Castelo-Grande T. Magnetic classification. Mineral Engineering, 2002;15:35-43. https://doi.org/10.1016/S08926875(01)00196-0

[17] Mantero J; Lehritane M; Hurtado S; García-Tenorio R. Radioanalytical determination of actinoids in refractory matrices by alkali fusion. J. Radioanal. Nucl. Chem. 2010;286:557-563. http://dx.doi.org/10.1007/s10967-010-0782-3

[18] Frantz Co. S. G., Inc. Assembly, Installation, Operation and Maintenance Instruction. Frantz Magnetic Separator. 1965.

[19] Cui Z, Liu Q, Etsell TH. Magnetic properties of ilmenite, hematite and oilsand minerals after roasting. Mineral Engineer. 2002;15:1121-1129. https://doi.org/10.1016/S0892-6875(02)00260-1

[20] Hutchison SC. Laboratory handbook of petrographic techniques. Wiley and Sons edit. 1974. 
[21] Chun Li, Bin Liang, Ling-hong Guo. Dissolution of mechanically active Panzhihua ilmenites in dilute solutions of sulphuric acid. Hydrometallurgy 2007;89:1-10.

[22] Chernet T. Mineralogical and textural constrainst on mineral processing of the Koivusaaarenneva ilmenite ore, Kälviä, western Finland. Int. J. Miner. Process, 1999;57:153-165.

[23] Pownceby MI, MacRae CM, Wilson NC. Mineral characterisation by EPMA mapping. Minerals Engineer. 2007;20:444-451. DOI:101016/j.mineng.2006.10.014

[24] Pownceby IM. Compositional and textural variation in detrital chrome-spinels from the Murray Basin, southeastern Australia. Mineralogical Magazine, 2005;69:191-204.

https://doi.org/10.1180/0026461056920246

[25] Kalinkina EV; Kalinkin AM; Forsling W; Makarov VN. Sorption of atmospheric carbon dioxide and structural changes of $\mathrm{Ca}$ and $\mathrm{Mg}$ silicate minerals during grinding: I. Diopside. Int, J. Miner. Process, 2001;61:273 - 288. DOI: 10.1016/S03017516(00)00035-1

[26] Pownceby MI, Sparrow GJ, Fisher-White MJ. Mineralogical characterisation of Eucla Basin ilmenite concentrates- First results from a new global resource. Miner. Engineer. 2008;21:587-597. https://doi.org/10.1016/j.mineng.2007.11.011

[27] http://webmineral.com/data/Pseudorutile.shtml\#.Vu $\underline{\mathrm{mi} O a P n K s}$

[28] Teufer G, Temple AK. Pseudorutile - a new mineral intermediate between ilmenite and rutile in the alteration of ilmenite. Nature, 1966;211:179-181. DOI: $10.1038 / 211179 b 0$
[29] Lahiri A, Jha A. Selective separation of rare earths and impurities from ilmenite ore by addition of $\mathrm{K}^{+}$and $\mathrm{Al}^{3+}$ ions. Hydrometallurgy 2009;95:254-261. https://doi.org/10.1016/j.hydromet.2008.06.004

[30] Mackowski SJ, Reaveley BJ.) Synthetic rutile production at Tiwest Joint Venture, Chandala. WA. In: Australasian Mining and Metallurgy, The Sir Maurice Mawby Memorial Volume, Monograph Series Monograph No. 19, Woodcock, J.T., Hamilton, J.K. (Eds.), The Australasian Institute of Mining and Metallurgy, Carlton, 1304-1308. 1993.

[31] Tejan-Kella MS, Fitzpatrick RW, Chittleborough DJ. Scanning electron microscope study of zircons and retiles from a podzol chronosequence at Cooloola, Queensland, Australia. Catena, 1991;18:11-30.

[32] Chernet T. Applied mineralogical studies on Australian sand ilmenite concentrate with special reference to its behaviour in the sulphate process. Mineral Engineering, 1999;12:485-495. https://doi.org/10.1016/S0892-6875(99)00035-7

[33] Temple AK. Alteration of ilmenite. Economic Geology, 1966;61:695-714. DOI: $10.2113 /$ gsecongeo.61.4.695

[34] Berrow ML, Wilson MJ, Reaves GA. Origin of extractable titanium and vanadium in the A horizons of Scottish podzols. Geoderma, 1978;21:89-103. https://doi.org/10.1016/0016-7061(78)90019-8

[35] Bull PA, Goudie AS, Williams DP, Watson A. Colluvium: a scanning electron microscope analysis of a neglected sediment type". In: Marshall, J.R. (ed.), Clastic Particles -- Scanning Electron Microscopy and Shape Analysis of Sedimentary and Volcanic Clastics. Reinhold, New York, 16-35. 1987. 